\title{
International genetic evaluations for feed intake in dairy cattle through the collation of data from multiple sources
}

\author{
D. P. Berry, ${ }^{\star 1}$ M. P. Coffey,† J. E. Pryce,‡ Y. de Haas,§ P. LøvendahI,\# N. Krattenmacher,॥ J. J. Crowley,

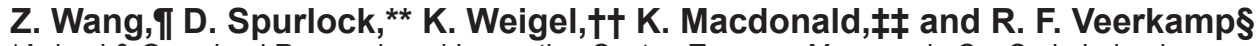 \\ ${ }^{*}$ Animal \& Grassland Research and Innovation Centre, Teagasc, Moorepark, Co. Cork, Ireland \\ †Animal and Veterinary Sciences, Scotland's Rural College (SRUC), Easter Bush Campus, Midlothian EH25 9RG, United Kingdom \\ †Department of Environment and Primary Industries \& Dairy Futures Cooperative Research Centre (CRC), Agribio, 5 Ring Road, \\ La Trobe University, Bundoora 3083, Australia \\ §Animal Breeding and Genomics Centre, Wageningen UR Livestock Research, 8200 AB Lelystad, the Netherlands \\ \#Department of Molecular Biology and Genetics, Aarhus University, DK-8830 Tjele, Denmark \\ IIInstitute of Animal Breeding and Husbandry, Christian-Albrechts-University, D-24118 Kiel, Germany \\ TIDepartment of Agricultural, Food and Nutritional Science, University of Alberta, Edmonton, Alberta T6G 2P5, Canada \\ ${ }^{* *}$ Department of Animal Science, lowa State University, Ames 50011 \\ ††Department of Dairy Science, University of Wisconsin, Madison 53706 \\ \$‡DairyNZ, Private Bag 3221, Hamilton 3248, New Zealand
}

\section{ABSTRACT}

Feed represents a large proportion of the variable costs in dairy production systems. The omission of feed intake measures explicitly from national dairy cow breeding objectives is predominantly due to a lack of information from which to make selection decisions. However, individual cow feed intake data are available in different countries, mostly from research or nucleus herds. None of these data sets are sufficiently large enough on their own to generate accurate genetic evaluations. In the current study, we collate data from 10 populations in 9 countries and estimate genetic parameters for dry matter intake (DMI). A total of 224,174 test-day records from 10,068 parity 1 to 5 records of 6,957 cows were available, as well as records from 1,784 growing heifers. Random regression models were fit to the lactating cow test-day records and predicted feed intake at $70 \mathrm{~d}$ postcalving was extracted from these fitted profiles. The random regression model included a fixed polynomial regression for each lactation separately, as well as herd-year-season of calving and experimental treatment as fixed effects; random effects fit in the model included individual animal deviation from the fixed regression for each parity as well as mean herdspecific deviations from the fixed regression. Predicted DMI at $70 \mathrm{~d}$ postcalving was used as the phenotype for the subsequent genetic analyses undertaken using an animal repeatability model. Heritability estimates of predicted cow feed intake $70 \mathrm{~d}$ postcalving was 0.34 across the entire data set and varied, within population, from 0.08 to 0.52 . Repeatability of feed intake across

Received October 1, 2013.

Accepted February 28, 2014.

${ }^{1}$ Corresponding author: donagh.berry@teagasc.ie lactations was 0.66. Heritability of feed intake in the growing heifers was 0.20 to 0.34 in the 2 populations with heifer data. The genetic correlation between feed intake in lactating cows and growing heifers was 0.67. A combined pedigree and genomic relationship matrix was used to improve linkages between populations for the estimation of genetic correlations of DMI in lactating cows; genotype information was available on 5,429 of the animals. Populations were categorized as North America, grazing, other low input, and high input European Union. Albeit associated with large standard errors, genetic correlation estimates for DMI between populations varied from 0.14 to 0.84 but were stronger (0.76 to 0.84 ) between the populations representative of high-input production systems. Genetic correlations with the grazing populations were weak to moderate, varying from 0.14 to 0.57 . Genetic evaluations for DMI can be undertaken using data collated from international populations; however, genotype-by-environment interactions with grazing production systems need to be considered.

Key words: feed intake, heritability, confinement, grazing, international collaboration

\section{INTRODUCTION}

Despite the large contribution $(\sim 60 \%)$ of feed to the variable costs of production in dairy cattle systems (Shalloo et al., 2004; Ho et al., 2005), feed intake is currently not explicitly included in the breeding goal of any dairy cattle population. This omission is principally due to an absence of sufficient feed intake information to estimate breeding values of individual animals. Feed intake data in dairy cattle are almost exclusively recorded in research herds or nucleus breeding herds. Therefore, despite the known existence of heritable ge- 
netic variation in feed intake in dairy cattle (Veerkamp and Thompson, 1999; Coffey et al., 2004; Berry et al., 2007), estimation of accurate breeding values for bulls is still not achieved because of the limited size of national data sets.

Collation of international data on feed intake and associated information from research herds and nucleus breeding herds is one approach to increase the quantity of feed intake data available for the estimation of breeding values. Banos et al. (2012) previously described an approach for the collation of research data from 4 European countries. Veerkamp et al. (2012) used these collated data to undertake a genome-wide association study for feed intake complex and were able to detect significant putative QTL for feed intake, which could not have been found in the individual data sets. de Haas et al. (2012) collated DMI data from Australia, the Netherlands, and the United Kingdom and demonstrated that the accuracy of genomic selection could be improved by combining data from several research populations. The objective of the present study was to collate phenotypic data on feed intake from 9 different countries across a range of production systems and to evaluate both the possibility and plausibility of combining these data for use in an international genetic evaluation for feed intake; data on performance traits other than feed intake (e.g., milk production, live weight) were not available. The present study will provide the necessary information for the estimation of breeding values in dairy cattle for feed intake and will determine the value of this combined data set as a potential reference population for genomic evaluations.

\section{MATERIALS AND METHODS}

Data on individual daily feed intake of Holstein-Friesian cows and heifers were available from 9 countries, with some countries providing data from more than 1 population of animals. Only cow data from parity 1 to 5 were retained for inclusion in the analysis; feed intake data from growing heifers ( $<2$ yr of age) in Australia and New Zealand were also available and retained for the analysis. Data on feed intake was transformed into DMI by multiplying wet feed intake by the respective DM content of that particular diet for the purposes of analysis. All animals were fed ad libitum.

\section{Wisconsin}

Data were available on average daily feed intake per week from 447 primiparous and multiparous cows from 7 designed feeding experiments at the University of Wisconsin Emmons Blaine Dairy Cattle Research Cen- ter (Arlington, WI) and 3 designed feeding experiments at the USDA, Agricultural Research Service, Dairy Forage Research Center (Prairie du Sac, WI; Ferraretto et al., 2011; He et al., 2012). These experiments were conducted between October 2007 and March 2012. All cows were fed a TMR and milked twice daily. Feed intake was measured using electronic (Insentec B.V., Marknesse, the Netherlands) feed gates. Average DM of the diets was $51 / 100 \mathrm{~g}$ and varied from 47.5 to $54.9 / 100 \mathrm{~g}$. Breed composition of these cows was $\geq 75 \%$ Holstein. In total, 5,797 weekly average DMI records between zero and 304 DIM from 447 lactations 1 to 5 on 447 cows were available. Cows were from 51 different experimental treatments.

\section{lowa}

Feed intake data were collected from 398 primiparous and multiparous Holstein cows at the Iowa State University Dairy between March 2008 and November 2010 (Spurlock et al., 2012). Data were collected from between approximately 2 and 150 DIM. This time period was chosen to characterize energy balance throughout the duration of negative energy balance, while optimizing the use of available facilities. Cows were milked twice daily.

Cows were housed in pens equipped with a Calan Broadbent Feeding system (American Calan Inc., Northwood, NH) and fed a TMR formulated to meet or exceed all nutritional requirements (NRC, 2001) throughout the experiment. The TMR was dispensed to each feed bin twice daily, and the quantity of feed dispensed at each feeding was electronically recorded. Refusals from each feed bin were removed and weighed daily. A sample of TMR was collected from at least 4 feedings per week and from orts on at least $3 \mathrm{~d} /$ wk. Equal quantities of these samples were combined to obtain separate weekly samples of TMR and orts. These weekly samples were analyzed to determine DM content. Average DM was 50.3 and 48.4/100 g for TMR and orts, respectively. Daily intake records were discarded if exactly 2 records of TMR fed and 1 record of orts were not recorded consecutively, or if DMI intake for the day was less than $2.0 \mathrm{~kg}$. The final data set consisted of 8,581 daily DMI test-day records between zero and 150 DIM from 398 lactations 1 to 3 on 398 cows. No experimental treatments were imposed on the cows.

\section{Canada}

The animals were housed in a tiestall system at Dairy Research and Technology Center of the University of Alberta from June 2007 to October 2011 (Manafiazar 
et al., 2013). Cows were individually offered feed in the morning and feed refusals were recorded daily. Offered feed was adjusted periodically so that refused feed remained at approximately $10 \%$ of the total feed offered. The animals, milked twice a day, received 1 of the 3 (high-, mid-, or low-yield ration) TMR diets according to their stage of lactation. Average DM content of the diet across the $5 \mathrm{yr}$ was $52.12 / 100 \mathrm{~g}$ for the high-yield TMR, 51.03/100 g for the mid-yield TMR, and 48.87/100 g for the low-yield TMR. The final data set consisted of 14,465 daily DMI records between zero and 302 DIM from 411 lactations 1 to 3 on 202 cows. Cows were from 74 different experimental treatments.

\section{Ireland}

Feed intake data originated from a series of experiments at Moorepark Dairy Production Research Centre in southern Ireland. The experiments undertaken related to the evaluation of alternative grazing strategies, nutritional strategies, and strain of Holstein-Friesian animals (Buckley et al., 2000; Kennedy et al., 2003; O'Donovan and Delaby, 2005; Horan et al., 2006; Kennedy et al., 2006). Animals were fed a basal grazedgrass diet on predominately perennial ryegrass (Lolium perenne) swards. Annual concentrate feeding levels across studies varied from 325 to $1,452 \mathrm{~kg} / \mathrm{cow}$. Average DM of the diet was 19.4/100 g and varied across the year. All cows calved in the spring and were milked twice daily.

Individual animal intake was measured while at pasture when the diet consisted of exclusively pasture or pasture plus concentrate, depending on the feed system. Individual animal intakes were estimated using the $n$-alkane technique (Mayes et al., 1986) as modified by Dillon (1993). During each intake period the cows were dosed twice daily (after milking) for a 12-d period with paper filters or bungs (Carl Roth $\mathrm{GmbH}$ and Co. KG, Karlsruhe, Germany) containing approximately $500 \mathrm{mg}$ of dotriacontane each. Fecal grab samples were collected twice daily from each cow immediately before or after milking in the last $6 \mathrm{~d}$. The fecal samples from each cow for each 6-d period were bulked for analysis. Herbage samples were collected manually to represent herbage grazed (following close observation of the grazing animal) after both the morning and evening milking on d 6 to 11 of each measurement period. The ratio of herbage tritriacontane to dosed dotriacontane was used to estimate intake. The $n$-alkane concentration of the dosed pellets, feces, herbage, and concentrate were determined as described by Dillon (1993). The final data set consisted of 5,487 weekly (only 1 measure) DMI records from 1,677 lactations 1 to 5 from 827 cows between 5 and 286 DIM.

\section{The Netherlands}

Feed intake data were available from Holstein-Friesian lactating cows kept indoors in conventional cubicle housings and offered complete mixed diets. All animals were generally milked twice a day (unless otherwise stated). Data on 688 lactating primiparous cows were collected on the Dutch farm 't Gen (Lelystad, the Netherlands) between 1991 and 1998 (Veerkamp et al., 2000). The farm had 2 genetic lines, a control line, and participants in the breeding program of CR-Delta (Arnhem, the Netherlands; i.e., high genetic line for milk yield). On average, the DM content of the TMR was $65 / 100 \mathrm{~g}$, as artificial dried grass was used. Data on 100 lactating parity 1 and 2 cows collected on the Dutch farm Nij Bosma Zathe (Leeuwarden, the Netherlands) between May 2003 and December 2004 (Beerda et al., 2007) were also available. At this farm, differences in milking frequencies (2 or 3 times daily) and feeding strategy (fed a TMR with low- or high-energy content) existed; DM of the diet varied from 48 to $49 / 100 \mathrm{~g}$. Data on 748 lactating parity 1 to 5 cows were collected on 6 different experimental herds (9 separate experimental sites) between 1991 and 2001 (Zom et al., 2012); average DM of the diets was $54 / 100 \mathrm{~g}$. Data on a further 705 lactating parity 1 to 5 cows collected on 1 experimental farm between 2003 and 2011 were also available. All these data were collected in 21 different experiments. Average DM of the diet fed was 50/100 g. The final data set consisted of 56,061 records (a combination of weekly average and daily records) between 7 and 301 DIM from 2,956 lactations 1 to 5 on 2,241 cows.

\section{United Kingdom}

Data originated from the Scottish Agricultural College (now SRUC) Dairy Research Centre based at Langhill herd, Edinburgh (Veerkamp et al., 1995; Pryce et al., 1999), up to September 2001, which was subsequently transferred to Crichton Royal Farm, Dumfries, Scotland. Data included in the present study was from the years 1990 to 2012, inclusive. The herd normally consisted of approximately 200 milking cows divided evenly between 2 genetic groups (control vs. selection) established in 1990 as part of an ongoing selection experiment. Cows in each genetic group were further split randomly into 2 diet groups fed a TMR - high concentrates (approximately 2,500 $\mathrm{kg}$ of concentrates per year with a diet DM content of 40/100g) versus high forage (approximately 1,500 kg of forage with a diet DM content of 30/100 g) - for the purposes of a feeding experiment. As of 2001, cows were milked 3 times daily; cows were milked twice daily before 2001 . 
Cow sires in the selection group were picked on the basis of genetic merit for milk fat and protein yield; available sires with the highest genetic evaluation for fat plus protein $(\mathrm{kg})$ being chosen at the time of AI. Sires of control group cows were selected to have the average genetic merit for fat plus protein $(\mathrm{kg})$ of UK animals at the time of breeding.

Animals were randomly allocated to either the highconcentrate or the high-forage (low-concentrate) group at first calving. Feed was offered in individual feed bins (HOKO-system, Insentec B.V.). The high-forage system consisted entirely of home-grown feeds, including maize and other whole-crop cereals, and the cows were grazed on grass during the summer months. The winter ration consisted of grass silage, maize silage, and full-grain silage alkalage at a ratio of 60:20:20 on a DM basis plus a protein supplement. The ration was fed as a TMR. At least $75 \%$ of the DM of the ration was designed to come from forages. The high-concentrate system cows were housed all year, with access to an exercise area during the summer months. Their ration also contained the 3 forages mentioned previously, in the same DM ratio to each other, with a supplement blend of energy and protein ingredients. Grab samples of the feed were taken each day from each bin, thoroughly mixed, and pooled for weekly DM analysis. A sample was analyzed each month for all the parameters used in the experiment, such as ME, CP, and ash. The final data set consisted of 87,155 daily DMI records between zero and 305 DIM from 2,840 lactations 1 to 4 on 1,277 cows. Cows were from 2 experimental treatments across the duration of the whole study period.

\section{Denmark}

Feed intake data originated from the Danish Cattle Research Centre farm (www.KFC-Foulum.dk), collected between the years 2002 and 2012. Cows were milked through an automatic milking system. Cows were fed a TMR in weigh bins (RIC-system, Insentec B.V.). During each milking, a planned quantity of concentrates was dispensed in the automatic milking system and leftovers were recorded. Components in the TMR differed over years but were mainly based on maize, whole-crop, and grass silage supplied with sugar-beet expellers and protein concentrates. Although the diets supplied over time differed and included (minor) various treatments, they all aimed at supporting high yield; therefore, for this study, were regarded as 1 single treatment. The DM and energy content in TMR and concentrates were analyzed on a regular basis and had their composition aligned and merged with intake records to obtain daily DM or energy intake for each cow. Average DM of the diet was 44/100 g. The final data set consisted of 21,668 weekly average DMI records between 1 and 302 DIM from 668 lactations 1 to 3 on 363 cows.

\section{Germany}

Data originated from the dairy research farm Karkendamm of the Christian-Albrechts-University Kiel in northern Germany and were collected between the years 2005 and 2012. During the whole recording period, a bull dam performance test was run in cooperation with the breeding company NOG (Nord-Ost Genetic GmbH and Co. KG, Verden, Germany). Approximately 80 primiparous cows were tested annually. All Karkendamm bull dam candidates had to complete a test period under commercial conditions in a freestall barn with a rotary milking parlor until 180 DIM. At d 180 of lactation, cows were selected as bull dams. Those that qualified finished the first lactation, whereas nonqualified cows left the herd and were returned to their breeders. The majority of the data was from primiparous cows, although the herd also consisted of multiparous cows owned by the university. These cows accounted for approximately $50 \%$ of the herd and were not selected according to the selection scheme described previously.

All cows were milked twice daily. Animals were fed a TMR diet. On average, the DM content of the TMR was $44 / 100 \mathrm{~g}$. Total mixed ration intake per day was recorded for each animal via single feeding troughs equipped with a weighing unit and automatic cow identification. As cows were generally housed separately during the first 10 DIM, no feed intake data were available for this period. A detailed description of the data editing procedure is given by Buttchereit et al. (2010). The final data set consisted of 24,523 weekly average DMI records from 14 to 301 DIM from 1,141 lactations 1 to 5 on 1,095 cows. All cows originated from 129 experimental treatments.

\section{Australia}

Data comprised 3 cohorts of Holstein growing heifers that were born in the spring of $2008(\mathrm{n}=294)$, autumn of $2009(\mathrm{n}=287)$, and spring of $2009(\mathrm{n}=302)$. The calves were sourced from 23 different farms, in northern Victoria, Australia, and were penned in groups of 15 to 20 , by farm of origin where possible, for up to $95 \mathrm{~d}$. This period included $25 \mathrm{~d}$ of acclimatization to the testing facilities followed by the test period. The average age when feed intake was measured was approximately 6 mo. The calves were fed the same diet of alfalfa hay that was pressed into $28-\mathrm{mm}$ cubes and had a DM of $85 / 100 \mathrm{~g}$. The diet was fed for a test period of 70 (cohort 1) and $60 \mathrm{~d}$ (cohort 2 and 3). All electronic and measuring devices in the feed intake measurement units 
were made by Gallagher Animal Management Systems (Hamilton, New Zealand). Full details of the trial and data editing procedures are presented by Williams et al. (2011) and Pryce et al. (2012). Average DMI across the test period was calculated.

The extreme $10 \%$ of the calves of cohorts 1 and 3 (i.e., the most and least efficient, as evaluated for residual feed intake; Williams et al., 2011) were kept for a trial to test if this difference in efficiency was maintained in lactating cows. Average daily feed intake per week was available on a total of 101 lactating cows across 2 cohorts. The measurement period was 32 and $37 \mathrm{~d}$ for the first and second trials, and the same electronic feed automated feed intake units were used to measure feed intake. The lactating cows were offered the same diet as the growing heifers (i.e., alfalfa hay compressed into cubes), but this was also supplemented by concentrates (on average $6.2 \mathrm{~kg} / \mathrm{d}$ ). The final data set consisted of a single record for 843 growing heifers and 460 average daily DMI per week records from 103 primiparous cows between 62 and 217 DIM.

\section{New Zealand}

Data consisted of 941 records from 941 growing Holstein-Friesian heifers aged 6 to 8 mo. All heifers resided on a single farm near Hawera, Taranaki, New Zealand. Heifer age at the commencement of the intake measurement was 215 d. Feed intake measurements were undertaken over a 3 -yr period (commencing in 2008), with measurements from the animals in a facility (uncovered) that can accommodate 224 individuals (28 pens, each holding 8 individuals). A full description of the experiment is given in Waghorn et al. (2012). Briefly, the heifers were fed alfalfa cubes $(\mathrm{DM}=85 / 100$ g) very similar to the Australian experiment and had access to the feed via a narrow chute; individual ID was recorded by an electronic ID reader mounted above the feed bin. The bins were constructed from molded polythene and sat on a platform over load cells. Four load cells supported each bin and weights were recorded at 0.02 -s intervals to an accuracy of $0.1 \mathrm{~kg}$. Intake data were collected over $49 \mathrm{~d}$.

\section{Data Collation and Prediction of Daily DMI}

In total, 233,189 feed intake records from 12,425 parities on 8,737 cows and heifers were available. Excluding the nulliparous animals, 231,405 DMI records from 10,641 parities from 6,953 cows remained.

Random regression models were used to interpolate and extrapolate phenotypic DMI information for all cows within lactation, so that each lactation had equivalent information for DMI across all DIM. Lactation profiles were only predicted for lactations that had at least 1 DMI observation. The random regression model fitted was

$$
\begin{aligned}
& \text { DMI }=\text { parity } \cdot \sum_{n=0}^{5} \mathrm{DIM}^{\mathrm{n}}+\mathrm{HYS} \_ \text {calving }+\mathrm{CG}+\text { parity } \cdot \text { animal } \\
& \sum_{\mathrm{n}=0}^{2} \mathrm{DIM}^{\mathrm{n}}+\text { herd } \cdot \sum_{\mathrm{n}=0}^{2} \mathrm{DIM}^{\mathrm{n}}+\mathrm{e}
\end{aligned}
$$

where parity $\cdot \sum_{n=0}^{5}$ DIM is a fixed effect for a fifth-order Legendre polynomial on DIM for each parity (1 to 5 ) separately; HYS_calving is the fixed effect of herdyear-month of calving; CG is contemporary group (i.e., experimental treatment) that varied for some populations across lactation; parity $\cdot$ animal $\cdot \sum_{n=0}^{2} \mathrm{DIM}$ is a random effect, second-order Legendre polynomial on DIM for the animal effect for each parity (1 to 5) separately; herd $\cdot \sum_{n=0}^{2}$ DIM is a random effect, second-order Legendre polynomial on DIM since calving for the herd effect; and $\mathrm{e}$ is the residual. Lactations were divided into 4 stages: $\leq 30$ DIM, 31 to 100 DIM, 101 to 200 DIM and $>200$ DIM. Records were categorized into different classes for the estimation of residual variance components based on population by stage of lactation by parity $(1,2,3+) ; 7$ classes had less than 10 records and were therefore merged to an adjacent lactation stage class within the same parity and population. A separate residual variance was fit for each of the 184 classes; no residual covariances were assumed.

Predicted DMI was obtained for each animal-parity for every DIM. The average contemporary group effect for each animal-lactation was absorbed into the herd-year-season of calving effect for the purposes of subsequent analysis.

\section{Generation of Relationship Matrix}

Single nucleotide polymorphism genotypes were available on 5,429 animals that also had phenotypic information in the current study. A total of 1,888 animals had Illumina high-density genotype (i.e., 777,962 $\mathrm{SNP}$ ) information and the remainder had genotype information from the Illumina Bovine50 BeadChip (i.e., 54,001 SNP; Illumina Inc., San Diego, CA). Imputation of Illumina high-density genotypes for 5,429 animals to 591,213 SNP was described in detail by Pryce et al. (2014). Monomorphic SNP, as well as SNP deviating from the Hardy-Weinberg equilibrium, were discarded and only autosomal SNP were retained. Following editing, 583,375 SNP remained for the calculation of the 
genomic relationship matrix. Pedigree information of all animals was traced back to the founder population; aliases in the pedigree were removed through the use of the Interbull identification cross-reference tables and manual curation of the pedigree. The total pedigree file consisted of 271,545 records.

The genomic relationship matrix $(\mathbf{G})$ was computed as described by VanRaden (2008):

$$
\mathbf{G}=\frac{\mathbf{Z Z}^{\prime}}{2 \sum p_{i}\left(1-p_{i}\right)},
$$

where $\mathbf{Z}$ contains the marker genotypes for all animals at all loci, corrected for the allele frequency per locus; and $p_{i}$ is the frequency of the second allele at locus $i$. Matrix $\mathbf{Z}$ is derived from the genotypes of the animals by subtracting 2 times the allele frequency (i.e., $2 p_{i}$ ) from matrix $\mathbf{X}$, which specifies the marker genotypes for each individual as 0,1 , or 2 . Values for $p_{i}$ were calculated from the data. Allele frequency differences between populations were not explicitly accounted for.

It is important that the relationship matrices combined in $\mathbf{H}^{-1}$ have similar scale (Forni et al., 2011; Vitezica et al., 2011). Therefore, the numerator relationship matrix for all genotyped individuals was computed $\left(\mathbf{A}_{22}\right)$. The inbreeding level in $\mathbf{G}$ was then scaled to the average inbreeding level in $\mathbf{A}_{\mathbf{2}}$, denoted as $\bar{f}_{p}$. As the current population was used to calculate $p_{i}$, the expectation of the average genomic inbreeding coefficient in $\mathbf{G}$ is zero. Then $\mathbf{G}^{*}$ was calculated following the formula derived from Wright's F-statistics as in Powell et al. (2010):

$$
\mathbf{G}^{*}=\mathbf{G}\left(1-\overline{f_{p}}\right)+2 f_{p} \mathbf{J}
$$

where $\mathbf{G}^{*}$ contains the relationships relative to the same base used in $\mathbf{A}_{22}$; and $\mathbf{J}$ is a matrix of all ones. This adjustment is equivalent to that proposed by Vitezica et al. (2011).

The combined pedigree and genomic relationship matrix $\left(\mathbf{H}^{-\mathbf{1}}\right)$ was computed as (Aguilar et al., 2010; Christensen and Lund, 2010):

$$
\mathbf{H}^{-1}=\mathbf{A}^{-1}+\left[\begin{array}{lc}
0 & 0 \\
0 & \lambda\left(\mathbf{G}^{-1}-\mathbf{A}_{22}^{-1}\right)
\end{array}\right] .
$$

Here, we chose a value of 1.0 for $\lambda$.

\section{Estimation of Genetic Parameters}

The phenotype used in subsequent analyses was DMI at 70 DIM (for cows) predicted from the random re- gression model. Dry matter intake at 70 DIM was only predicted for lactations where at least 1 actual DMI observation in that lactation existed for the animal. Seventy DIM was chosen because this was the period when the largest number of actual DMI observations existed within the data set, but it is also close to the critical period of early lactation.

Phenotypic and genetic variance components for predicted DMI at 70 DIM were estimated in each country separately, as well as in a combined data set; variance components were estimated using the traditional relationship matrix derived from pedigree information, as well as using the combined pedigree and genomic relationship matrix. An animal (across lactation) repeatability linear mixed model was used to estimate all variance components; the fixed effects included in the model were parity and herd-year-season of calving. The genetic correlation between growing heifer DMI (measured at about 6 mo of age) and lactating cow DMI (using cow data from all countries) was also estimated using an animal model.

Lactating cow records within populations were grouped as North America (Iowa + Wisconsin + Canada), Grazing (Ireland + Australia), EU high input (UK high-input feeding system + the Netherlands + Germany + Denmark), and EU low input (UK lowinput feeding system). Genetic covariances for DMI between populations were estimated using the animal model previously described with the combined pedigree and genomic relationship matrix; no residual or permanent environmental covariances were assumed between countries.

\section{RESULTS AND DISCUSSION}

Generating accurate estimates of genetic merit for any trait, including feed intake, requires access to large quantities of data; the quantity required to achieve a certain level of accuracy is dependent on the heritability, which in turn depends on the accuracy of recording the phenotype. No national dairy cow breeding goal directly includes feed intake of lactating animals, primarily because of a paucity of the necessary feed intake data within the population. This lack of data is simply an artifact of the high cost and large resources required to accurately record such information in a large enough population of animals. Combining data from different populations, each covering their own individual costs of data procurement, could be a sensible strategy to achieve high accuracy of selection for such difficult to measure traits. Although genomic selection is now being used in most international dairy breeding programs (Hayes et al., 2009; Spelman et al., 2013), accurate genomic prediction still requires access to a large 
population of phenotyped individuals. The data used in the present study originated from several populations differing in several aspects, including feeding system (i.e., confinement-fed TMR or alfalfa cubes vs. grazing), measurement technique for feed intake (i.e., Calan gates, HOKO feed system, and $n$-alkanes), period of data collection (data originated over a 23-yr time span), and genetic ancestry of the animals. Moreover, no other performance data other than feed intake were available to the present study to elucidate the genetic correlations between DMI and other performance traits in each population. Furthermore, access to additional performance data could be useful in a multitrait genetic evaluation to not only increase the accuracy of selection for DMI but also account for potential selection bias, which may exist in animals with data in later parities without also having data in earlier parities, as existed in the data set used in the present study. Having performance data on which to estimate breeding values for inclusion in national breeding goals with feed intake is a key component of an overall strategy to improve production efficiency.

The ability to derive a common pedigree file in the present study was greatly aided by the international pedigree file generated by Interbull. In the absence of such a resource, the necessary file would have to be created and have aliases resolved. An international initiative is underway in beef cattle through Interbeef to generate an international beef pedigree file.

\section{Performance Statistics}

Mean lactation profiles for first-lactation DMI for each population are in Figure 1. Data from the United Kingdom was separated into 2 groups to reflect the high and low feeding systems in that population (Pryce et al., 1999). The stage of lactation when DMI was measured in the Australian lactating cow population varied from 62 to 217 DIM, so no information was available in early lactation; hence, interpretation of the early lactation DMI predictions in this population of limited size should be made with caution. Dry matter intake was, on average, greatest in both US populations (i.e., Iowa and Wisconsin) and was lowest for Ireland, Australia, and the low-input feed system in the United Kingdom. The differences observed are likely a function of the diet fed, but also the genetic merit of the cows in both production systems. High-forage diets and their associated high gut-filling capacity (Gill et al., 1988) will limit intake capacity; cows in the Irish data set were fed predominantly grazed grass, cows in Australia were fed Lucerne cubes, and cows on the low-input diet in the United Kingdom had a high proportion of forage in the diet (Pryce et al., 1999). Moreover, in Ireland at least, genetic selection has not occurred for large body size and high-yielding animals. Genetic selection for increased body size and milk yield will, on average, increase genetic merit for DMI (Veerkamp and Brotherstone, 1997). Nonetheless, the shape of the DMI lactation profile was relatively consistent across populations, despite the random regression model applied in the present study facilitating the modeling of different lactation profiles for the different populations.

Random regression models have been used in several studies to interpolate or extrapolate missing values (Park and Lee, 2006; Kranis et al., 2007; Banos et al., 2012) so that records for all points on a trajectory (e.g., DIM) are available for all animals. Banos et al. (2012) successfully fit random regression models to performance data across research herds from 3 countries (which were a subset of the present data set) to impute missing values for a range of performance traits, including DMI.

Mean DMI at 70 DIM for the different populations is given in Table 1. Mean DMI of the nulliparous growing heifers was less than half the DMI of the lactating cows, although differences in diets fed will also have influenced this comparison. Nonetheless, lower DMI in heifers compared with older cows is expected, as growing heifers, although requiring energy for growth, have a smaller body size relative to lactating animals and do not require energy for lactation.

\section{Heritability and Repeatability}

The heritability of DMI in lactating cows (Table 1) in the entire data set was 0.34 (0.03) when estimated using the pedigree relationship matrix and $0.27(0.02)$ when estimated using the combined pedigree and genomic relationship matrix. These estimates are consistent with most recent international estimates for feed intake in dairy cows in both confinement (0.10-0.60; Veerkamp and Brotherstone, 1997; Søndergaard et al., 2002; Hüttmann et al., 2009; Vallimont et al., 2011; Spurlock et al., 2012) and grazing (Berry et al., 2007) production systems. Differences in heritability estimates derived from pedigree only or pedigree plus genomic information have been reported elsewhere (Veerkamp et al., 2011). The heritability of DMI estimated in the present study was also similar to that of many other performance traits, such as milk yield, live weight, and BCS (Veerkamp and Brotherstone, 1997; Berry et al., 2003; Toshniwal et al., 2008), which are known to contribute to the genetic variation in DMI (Berry and Crowley, 2013).

Within a population, heritability estimates for DMI (Table 1) varied from 0.08 (Germany) to 0.52 (Denmark) when estimated using the pedigree relationship 
Table 1. Number of lactations and animals, as well as the mean, genetic SD ( $\sigma_{\mathrm{g}}$; estimated using the pedigree relationship matrix), heritability (estimated using the pedigree-derived relationship matrix or combined pedigree plus genomic relationship matrix), and repeatability of DMI in all countries (i.e., all countries) or each individual country

\begin{tabular}{|c|c|c|c|c|c|c|c|}
\hline Country & Lactation & Cow & $\begin{array}{c}\text { Mean } \\
(\mathrm{kg} \text { of DM/d) }\end{array}$ & $\sigma_{\mathrm{g}}(\mathrm{kg}$ of $\mathrm{DM} / \mathrm{d})$ & \multicolumn{2}{|c|}{ Heritability } & Repeatability \\
\hline \multicolumn{8}{|l|}{ Cow } \\
\hline Canada & 411 & 202 & 22.2 & 1.01 & $0.19(0.14)$ & $0.11(0.11)$ & $0.46(0.06)$ \\
\hline Denmark & 668 & 363 & 22.1 & 1.48 & $0.52(0.12)$ & $0.46(0.12)$ & $0.62(0.04)$ \\
\hline Germany & 1,141 & 1,095 & 20.2 & 0.64 & $0.08(0.06)$ & $0.16(0.06)$ & $0.84(0.05)$ \\
\hline Netherlands & 2,956 & 2,241 & 21.4 & 1.15 & $0.39(0.05)$ & $0.38(0.04)$ & $0.54(0.03)$ \\
\hline United Kingdom & 2,840 & 1,277 & 17.4 & 1.07 & $0.31(0.06)$ & $0.30(0.06)$ & $0.72(0.02)$ \\
\hline Wisconsin & 447 & 447 & 24.9 & 0.90 & $0.24(0.16)$ & $0.19(0.13)$ & \\
\hline Australia & 103 & 103 & 15.6 & & & & \\
\hline \multicolumn{8}{|l|}{ Heifer } \\
\hline Australia & & 843 & 8.3 & 0.77 & $0.20(0.11)$ & $0.39(0.08)$ & \\
\hline New Zealand & & 941 & 7.6 & 0.66 & $0.34(0.12)$ & $0.25(0.07)$ & \\
\hline
\end{tabular}

matrix and from 0.11 (Canada) to 0.58 (Iowa) when estimated using the combined pedigree and genomic relationship matrix; heritability could not be estimated in the 103 Australian lactating dairy cows because they were a divergent population (i.e., heifers were retained based on extreme phenotypes) and were limited in size. The relatively low heritability estimate of DMI in the German population (0.08) when estimated using the pedigree relationship matrix is consistent with that documented using a similar German data set (Buttchereit et al., 2011), but increased (0.16) when the pedi- gree relationships were supplemented with the genomic information. Many of the within-country heritability estimates were in close proximity to each other and are consistent with previously published heritability estimates for these populations (Veerkamp and Brotherstone, 1997; Veerkamp and Thompson, 1999; Coffey et al., 2001; Berry et al., 2007; de Haas et al., 2012; Spurlock et al., 2012) and elsewhere (Søndergaard et al., 2002; Vallimont et al., 2011). Differences in feeding system and diet (i.e., TMR vs. grazing vs. alfalfa cubes), measurement protocols of feed intake (e.g.,

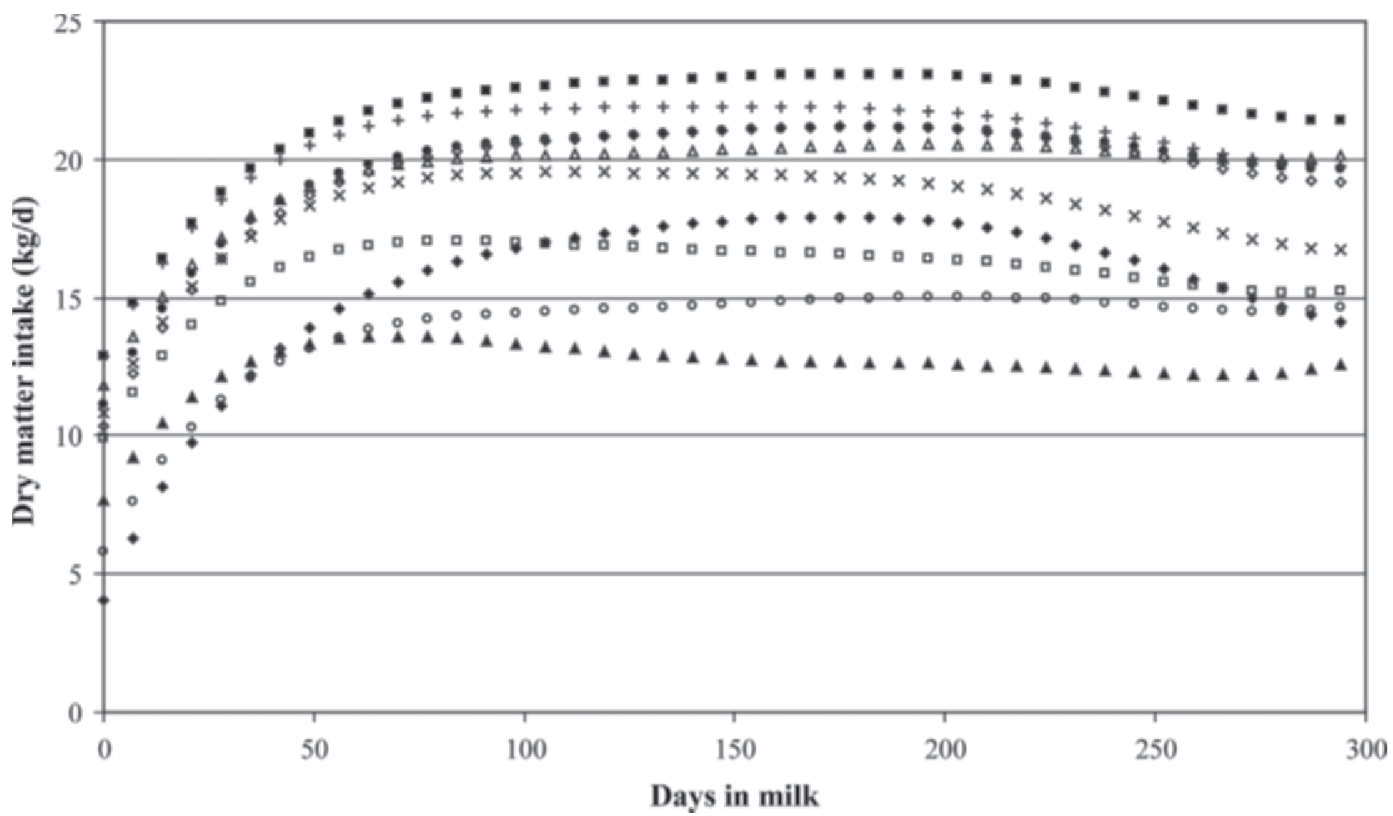

Figure 1. Predicted daily DMI across lactation for first-parity cows from the United Kingdom low-input feed system $(\mathbf{\Lambda})$, Ireland $(\bigcirc)$, Australia $(\diamond)$, United Kingdom high-input feed system $(\square)$, the Netherlands $(\times)$, Denmark $(\Delta)$, Canada $(\bullet)$, Germany $(\diamond)$, Iowa $(+)$, and Wisconsin (ם). 
Calan gate, HOKO feeders, $n$-alkanes), experimental designs, and germplasm are examples of factors likely contributing to differences in variance components, and thus heritability estimates, in the different populations studied.

Heritability of DMI in the nulliparous heifers was 0.20 and 0.34 for New Zealand and Australia, respectively, when estimated using the pedigree relationship matrix (Table 1), and the latter estimate has been discussed elsewhere (Lin et al., 2013). These heritability estimates of DMI are consistent with previously documented estimates in growing animals (for review see Berry and Crowley, 2013).

The genetic SD for DMI in lactating animals (Table 1) varied from 0.64 (Germany) to $1.48 \mathrm{~kg}$ of $\mathrm{DM} / \mathrm{d}$ (Iowa and Denmark). This suggests a coefficient of genetic variation of between 3.1 and $6.7 \%$. Taking note of the differences in heritability estimates between populations, the phenotypic SD for DMI in the lactating animals was very similar, varying from 1.84 (Wisconsin) to $2.32 \mathrm{~kg}$ of $\mathrm{DM}$ (Canada); the exception was lactating cows in Ireland $(1.38 \mathrm{~kg}$ of $\mathrm{DM} / \mathrm{d})$. Ireland operates a dairy production system relying predominantly on grazed grass, and grazed grass constituted almost all of the diet of the Irish cows included in the analysis. The coefficient of genetic variation for DMI in the nulliparous heifers was 8.7 to $9.3 \%$. The coefficient of genetic variation for DMI in the present study is consistent with estimates reported or calculated from other populations (Toshniwal et al., 2008), but also for other dairy cow performance traits, such as milk yield, live weight, BCS, and fertility (Berry et al., 2003).

Across lactation, repeatability estimates for DMI in the lactating animals (Table 1) was 0.66 in the entire population and varied from 0.46 (Canada) to 0.84 (Germany); no repeated records existed for the Iowa, Wisconsin, or Australian lactating cow data sets or for either heifer data set. Repeatability estimates were identical when estimated using either the pedigree-based or combined pedigree and genomic relationship matrix (results not shown). Across-lactation repeatability estimates for DMI in different populations of lactating dairy cows are lacking, but the estimates in the present study are consistent with the across-lactation repeatability estimate of 0.51 documented by Søndergaard et al. (2002) in 293 Danish lactating dairy cows of 3 different breeds.

\section{Genetic Correlations Between Countries}

The genetic correlations between DMI in different groups of countries are presented in Table 2. Genetic correlations estimated using the pedigree relationship matrix were in some cases negative, but were also as- sociated with large SE most likely due to poor genetic connectedness between some populations (results not shown). Mark et al. (2005), using a traditional relationship matrix, estimated genetic correlations between 9 weakly linked Ayrshire populations and documented vastly different estimates of the same pair-wise genetic correlation across the 5 statistical approaches investigated. Therefore, only genetic correlations estimated using the combined pedigree and genomic relationship matrix are presented and discussed (Table 2). The genetic correlations between both the European Union and North American populations were positive (0.76 to $0.84)$. Genetic correlations with the grazing population, however, were weaker and varied from 0.14 (grazing and North America) to 0.57 (grazing and low input EU). These weak genetic correlations indicate that genotypeby-environment interactions may exist for DMI in divergent production systems (confinement production systems fed energy-dense diets vs. grazing production systems) or that they are genetically different traits. Nonetheless, the SE of (some of) the genetic correlations were quite large, reflecting both the relatively small data set size in some countries but also the lack of strong genetic connectedness between populations; hence, the weaker than unity genetic correlations could also be explained by estimation bias. In general, the genetic correlations between milk production measured among countries reflecting confinement production systems (United States, Canada, the Netherlands) or among countries representing grazing production systems (Ireland and New Zealand) are stronger than the genetic correlations between the confinement production systems countries and the grazing production system countries (https://www.interbull.slu). The genetic correlation for milk production between all participating Holstein populations in Interbull and Holsteins in New Zealand (i.e., milk production from predominantly grazed grass) varied from 0.75 to 0.78 , with the exception of Ireland, where the genetic correlation with milk production in New Zealand was 0.85 ; milk production in Ireland is also predominantly produced from grazed grass. Tyrisevä et al., (2011) also documented weak genetic correlations for protein yield and SCC in different countries with those in New Zealand.

Animal characteristics influencing DMI in confinement and grazing production systems are likely to differ. For example, (rumen) capacity is likely to have a greater influence on DMI in grazing production systems because of the high gut-filling capacity associated with grass (Gill et al., 1988). Furthermore, cattle genotypes that can digest and absorb digesta from high-starch diets without any undesirable digestive consequences are likely to perform best in confinement production systems, whereas the ability to digest forage, and also 
Table 2. Genetic correlations (below diagonal; SE in parentheses) between DMI measured in groups of countries, as well as the number of sires common (above diagonal; sires plus maternal grandsires in common in parentheses) between the groups of countries ${ }^{2}$

\begin{tabular}{lcccc}
\hline Region & North America & EU high input & EU low input & Grazing \\
\hline North America & & $39(72)$ & $4(10)$ & $6(8)$ \\
EU high input & $0.76(0.21)$ & & $125(144)$ & $23(28)$ \\
EU low input & $0.79(0.38)$ & $0.84(0.14)$ & & $4(4)$ \\
Grazing & $0.14(0.43)$ & $0.33(0.20)$ & $0.57(0.43)$ & \\
\hline
\end{tabular}

${ }^{1}$ North America $=$ Iowa + Wisconsin + Canada; EU high input $=$ the Netherlands + Germany + Denmark + high-input feeding treatment in the United Kingdom; EU low input = low-input feeding treatment in the United Kingdom; Grazing = Ireland + Australia.

${ }^{2}$ Correlations were estimated using a combined pedigree and genomic relationship matrix.

the urge to graze, are likely to be characteristics of high DMI in grazing production systems. Differences between populations in techniques used to measure DMI, as well as protocols used to measure DMI, are also likely to contribute to non-unity genetic correlations; the $n$-alkane technique was used in Ireland to measure grass intake, whereas Calan gates or HOKO feeders for example were used in other populations. The existence of weak genetic correlations between DMI in grazing environments compared with higher input production systems suggest that cognizance must be taken of the production system when deciding on what data can be appropriately collated for use in an international genetic evaluation. Moreover, the genetic correlation structure among populations for DMI, as undertaken here, must first be estimated to determine the usefulness of collating such data and how best to include these data in a genetic evaluation.

\section{Genetic Correlations Between Growing Heifers and Lactating Cows}

The genetic correlation between nulliparous heifer DMI and that of lactating cows at $70 \mathrm{~d}$ postcalving (from all countries) was $0.67(0.24)$. This is consistent with the genetic correlation of 0.74 reported by Nieuwhof et al. (1992) between growing nulliparous heifers $(\mathrm{n}=417)$ and first-lactation cows $(\mathrm{n}=360)$ in early to midlactation. However, the diets (and other management factors) that both the heifers and cows were exposed to in the present meta-analysis study differ, as only 101 Australian animals had DMI observations both as heifers and cows and no New Zealand cows were included in the analysis. Nonetheless, the moderate to strong genetic correlation between heifer DMI and cow DMI suggests that the former may be a useful predictor of genetic merit for DMI in lactating cows, although further research either validating or refuting this conclusion on a larger data set with a more precise genetic correlation estimate is required. Measurement of DMI in heifers may be more feasible, as the management regimen of heifers can be disturbed for a short period to measure DMI without any considerable consequences on performance. Moreover, cows are sometimes fed to yield, which can distort the estimated genetic parameters.

\section{CONCLUSIONS}

Genetic variation in DMI existed for all populations included in the current study, and in most populations the heritability estimates ranged from 0.11 to 0.58 , which is consistent with the international literature as well as heritability estimates of other performance traits. Genetic correlation estimates between populations varied from 0.14 to 0.84 , but were stronger $(0.76$ to 0.84 ) between the populations representative of highinput production systems. This suggests the feasibility of collating DMI data from at least high-input production systems, but also indicates that genotype-byenvironment interactions should be properly accounted for when also utilizing DMI data from low-input grazing environments. Moreover, a greater understanding of this genotype-by-environment interaction, if it truly exists, is needed, as well as a better elucidation of the biological mechanisms governing genetic differences in DMI. The lack of strong genetic linkages between populations suggests a potential benefit of the development of a pan-global panel of proven bulls that could be recommended for use in research populations to facilitate better genetic connectedness among populations. The benefit of such an initiative, however, may be reduced if the traditional numerator relationship matrix is replaced by a genomic relationship matrix which is more accurate at detecting relationships among animals.

\section{ACKNOWLEDGMENTS}

Financial support for the global Dry Matter Initiative (gDMI) from CRV (Arnhem, the Netherlands), Irish Cattle Breeding Federation (ICBF, Cork, Ireland), Confederacion de Asociaciones de Frisona Española 
(CONAFE, Madrid, Spain), DairyCo (Warwickshire, UK), and The Natural Science and Engineering Research Council of Canada and DairyGen Council of Canadian Dairy Network (Guelph, ON, Canada) is gratefully appreciated, as well as the European Union FramWork7 International Research Staff Exchange Scheme (EU FP7 IRSES) SEQSEL (Grant no. 317697). The UK research data collection was funded by the Scottish Government (Victoria Quay, Edinburgh, UK). The Dutch research data collection was funded by projects paid by industry (CRV), the Dairy Product Board [Productschap Zuivel (PZ), Zoetermeer, the Netherlands], and by the Dutch Ministry of Agriculture (The Hague, the Netherlands). The WhyDry-project (Wageningen University, the Netherlands) is acknowledged for providing data as well. The Australian Research was funded by the Gardiner Foundation (Melbourne, Australia), Department of Environment and Primary Industries (DEPI, Melbourne, Australia), and Dairy Future's Cooperative Research Centre (CRC, Melbourne, Australia). The New Zealand research was funded by New Zealand farmers through DairyNZ. The US research was funded by the National Institute of Food and Agriculture Grant no. 0224899, from the USDA (Washington, DC). The RobustMilk project was financially supported by the European Commission (Brussels, Belgium) under the Seventh Research Framework Program, Grant Agreement Knowledge-Based Bio-Economy (KBBE)-21170. This study (SEQSEL; Project Number 317697) was also partly funded by the European Commission under the Seventh Research Framework Program IRSES. The content of this paper is the sole responsibility of the authors and it does not necessarily represent the views of the Commission or its services. Gratitude is also expressed to Mario Calus (Animal Breeding and Genomics Centre of Wageningen UR Livestock Research, Wageningen, the Netherlands) in the development of the combined pedigree and genomic relationship matrix.

\section{REFERENCES}

Aguilar, I., I. Misztal, D. Johnson, A. Legarra, S. Tsuruta, and T. Lawlor. 2010. Hot topic: A unified approach to utilize phenotypic, full pedigree, and genomic information for genetic evaluation of Holstein final score. J. Dairy Sci. 93:743-752.

Banos, G., M. P. Coffey, R. F. Veerkamp, D. P. Berry, and E. Wall 2012. Merging and characterizing phenotypic data on conventional and rare traits from dairy cattle experimental resources in three countries. Animal 6:1040-1048.

Beerda, B., W. Ouweltjes, L. B. J. Sebek, J. J. Windig, and R. F. Veerkamp. 2007. Effects of genotype by environment interactions on milk yield, energy balance, and protein balance. J. Dairy Sci. 90:219-228.

Berry, D. P., F. Buckley, P. Dillon, R. D. Evans, and R. F. Veerkamp. 2003. Genetic parameters for body condition score, body weight, milk yield, and fertility estimated using random regression models. J. Dairy Sci. 86:3704-3717.
Berry, D. P., and J. J. Crowley. 2013. Genetics of feed efficiency in dairy and beef cattle. J. Anim. Sci. 91:1594-1613.

Berry, D. P., B. Horan, M. O'Donovan, F. Buckley, E. Kennedy, M. McEvoy, and P. G. Dillon. 2007. Genetics of grass dry matter intake, energy balance, and digestibility in grazing Irish dairy cows. J. Dairy Sci. 90:4835-4845.

Buckley, F., P. Dillon, M. Rath, and R. F. Veerkamp. 2000. The relationship between genetic merit for yield and liveweight, condition score and energy balance of spring calving Holstein-Friesian dairy cows on grass based systems of milk production. J. Dairy Sci. 83:1878-1886

Buttchereit, N., E. Stamer, W. Junge, and G. Thaller. 2010. Evaluation of five lactation curve models fitted for fat:protein ratio of milk and daily energy balance. J. Dairy Sci. 93:1702-1712.

Buttchereit, N., E. Stamer, W. Junge, and G. Thaller. 2011. Genetic relationships among daily energy balance, feed intake, body condition score, and fat to protein ratio of milk in dairy cows. J. Dairy Sci. 94:1586-1591.

Christensen, O. F., and M. S. Lund. 2010. Genomic prediction when some animals are not genotyped. Genet. Sel. Evol. 42:2

Coffey, M. P., G. E. Emmans, and S. Brotherstone. 2001. Genetic evaluation of dairy bulls for energy balance traits using random regression. Anim. Sci. 73:29-40.

Coffey, M. P., G. Simm, J. D. Oldham, W. G. Hill, and S. Brotherstone. 2004. Genotype and diet effects on energy balance in the first three lactations of dairy cows. J. Dairy Sci. 87:4318-4326.

de Haas, Y., M. P. L. Calus, R. F. Veerkamp, E. Wall, M. P. Coffey, H. D. Daetwyler, B. J. Hayes, and J. E. Pryce. 2012. Improved accuracy of genomic prediction for dry matter intake of dairy cattle from combined European and Australian data sets. J. Dairy Sci. 95:6103-6112.

Dillon. P. 1993. The use of n-alkanes as markers to determine intake, botanical composition of available or consumed herbage in studies of digesta kinetics with dairy cows. PhD Thesis. National University Ireland, Dublin, Ireland.

Ferraretto, L. F., R. D. Shaver, M. Espineira, H. Gencoglu, and S. J. Bertics. 2011. Influence of a reduced-starch diet with or without exogenous amylase on lactation performance by dairy cows. J. Dairy Sci. 94:1490-1499.

Forni, S., I. Aguilar, and I. Misztal. 2011. Different genomic relationship matrices for single-step analysis using phenotypic, pedigree and genomic information. Genet. Sel. Evol. 43:1.

Gill, M., A. J. Rook, and L. R. S. Thiago. 1988. Factors affecting the voluntary intake of roughages by the dairy cow. Pages 262-279 in Nutrition and Lactation in the Dairy Cow. Butterworths, London, UK.

Hayes, B. J., P. J. Bowman, A. J. Chamberlain, and M. E. Goddard. 2009. Invited review: Genomic selection in dairy cattle: Progress and challenges. J. Dairy Sci. 92:433-443.

He, M., K. L. Perfield, H. B. Green, and L. E. Armentano. 2012. Effect of dietary fat blend enriched in oleic or linoleic acid and monensin supplementation on dairy cattle performance, milk fatty acid profiles, and milk fat depression. J. Dairy Sci. 95:1447-1461.

Ho, C., R. Nesseler, P. Doyle, and B. Malcolm. 2005. Future dairy farming systems in irrigation regions. Aust. Farm Bus. Manage. J. $2: 59-68$.

Horan, B., P. Faverdin, L. Delaby, M. Rath, and P. Dillon. 2006. The effect of strain of Holstein-Friesian dairy cows and pasture-based system on grass intake and milk production. Anim. Sci. 82:435444.

Hüttmann, H., E. Stammer, W. Junge, G. Thaller, and E. Kalm. 2009. Analysis of feed intake and energy balance of high-yielding first lactating Holstein cows with fixed and random regression models. Animal 3:181-188.

Kennedy, E., M. O'Donovan, J. P. Murphy, F. P. O'Mara, and L. Delaby. 2006. The effect of initial grazing date and subsequent stocking rate on the grazing management, grass dry matter intake and milk production of dairy cows in summer. Grass Forage Sci 61:375-384

Kennedy, J., P. Dillon, P. Faverdin, L. Delaby, G. Stakelum, and M. Rath. 2003. Effect of genetic merit and concentrate supplementa- 
tion on grass intake and milk production with Holstein-Friesian dairy cows. J. Dairy Sci. 86:610-621.

Kranis, A., G. Su, D. Sorensen, and J. A. Williams. 2007. The application of random regression models in the genetic analysis of monthly egg production in turkeys and a comparison with alternative longitudinal models. Poult. Sci. 86:470-475.

Lin, Z., I. Macleod, and J. E. Pryce. 2013. Estimation of genetic parameters for residual feed intake and feeding behavior traits in dairy heifers. J. Dairy Sci. 96:2654-2656.

Manafiazar, G., T. McFadden, L. Goonewardene, E. Okine, J. Basarab, P. Li, and Z. Wang. 2013. Prediction of residual feed intake for first-lactation dairy cows using orthogonal polynomial random regression. J. Dairy Sci. 96:7991-8001.

Mark, T., P. Madsen, J. Jensen, and W. F. Fikse. 2005. Difficulties in estimating across-country genetic correlations for weakly linked bull populations. J. Dairy Sci. 88:3303-3305.

Mayes, R. W., C. S. Lamb, and P. M. Colgrove. 1986. The use of dosed and herbage n-alkanes as markers for the determination of herbage intake. J. Agric. Sci. Camb. 107:161-170.

NRC. 2001. Nutrient Requirements of Dairy Cattle. 7th rev. ed. Natl. Acad. Sci., Washington, DC.

Nieuwhof, G. J., J. A. M. van Arendonk, H. Vos, and S. Korver. 1992 Genetic relationships between feed intake, efficiency and production traits in growing bulls, growing heifers and lactating heifers. Livest. Prod. Sci. 32:189-202.

O'Donovan, M., and L. Delaby. 2005. A comparison of perennial ryegrass cultivars differing in heading date and grass ploidy with spring calving dairy cows grazed at two different stocking rates. Anim. Res. 54:337-350.

Park, B., and D. Lee. 2006. Prediction of future milk yield with random regression model using test-day records in Holstein cows. Asian-australas. J. Anim. Sci. 19:915-921.

Powell, J. E., P. M. Visscher, and M. E. Goddard. 2010. Reconciling the analysis of IBD and IBS in complex trait studies. Nat. Rev. Genet. 11:800-805.

Pryce, J. E., J. Arias, P. J. Bowman, S. R. Davis, K. A. MacDonald G. C. Waghorn, W. J. Wales, Y. J. Williams, R. J. Spelman, and B. J. Hayes. 2012. Accuracy of genomic predictions of residual feed intake and 250 body weight in growing heifers using 625,000 SNP markers. J. Dairy Sci. 95:2108-2119.

Pryce, J. E., J. Johnston, B. J. Hayes, G. Sahana, K. A. Weigel, S. McParland, D. Spurlock, N. Krattenmacher, R. J. Spelman, E. Wall, and M. P. L. Calus. 2014. Imputation of genotypes from low density (50k) to high density (700k) of cows from research herds in Europe, North America and Australasia using 2 reference populations. J. Dairy Sci. 97:1799-1812.

Pryce, J. E., B. L. Nielsen, R. F. Veerkamp, and G. Simm. 1999 Genotype and feeding system effects and interactions for health and fertility traits in dairy cattle. Livest. Prod. Sci. 57:193-201.

Shalloo, L., P. Dillon, M. Rath, and M. Wallace. 2004. Description and validation of the Moorepark Dairy Systems Model (MDSM). J. Dairy Sci. 87:1945-1959.

Søndergaard, E., M. K. Sørensen, I. L. Mao, and J. Jensen. 2002. Genetic parameters of production, feed intake, body weight, body composition, and udder health in lactating dairy cows. Livest. Prod. Sci. 77:23-34.

Spelman, R., B. J. Hayes, and D. P. Berry. 2013. Use of molecular technologies for the advancement of animal breeding: Genomic se- lection in dairy cattle populations in Australia, Ireland and New Zealand. Anim. Prod. Sci. 53:869-875.

Spurlock, D. M., J. C. Dekkers, R. Fernando, D. A. Koltes, and A. Wolc. 2012. Genetic parameters for energy balance, feed efficiency, and related traits in Holstein cattle. J. Dairy Sci. 95:5393-5402.

Toshniwal, J. K., C. D. Dechow, B. G. Cassell, J. A. D. R. N. Appuhamy, and G. A. Varga. 2008. Heritability of electronically recorded daily body weight and correlations with yield, dry matter intake, and body conditions core. J. Dairy Sci. 91:3201-3210.

Tyrisevä, A.-M., K. Meyer, F. F. Ikse, V. Ducrocq, J. Jakobsen, M. H. Lidauer, and E. A. Mäntysaari. 2011. Principal component approach in variance component estimation for international sire evaluation. Genet. Sel. Evol. 43:21.

Vallimont, J. E., C. D. Dechow, J. M. Daubert, M. W. Dekleva, J. W. Blum, C. M. Barlieb, W. Liu, G. A. Varga, A. J. Heinrichs, and C. R. Baumrucker. 2011. Short communication: Heritability of gross feed efficiency and associations with yield, intake, residual intake, body weight, and body condition score in 11 commercial Pennsylvania tie stalls. J. Dairy Sci. 94:2108-2113.

VanRaden, P. M. 2008. Efficient methods to compute genomic predictions. J. Dairy Sci. 91:4414-4423.

Veerkamp, R. F., and S. Brotherstone. 1997. Genetic correlations between linear type traits, food intake, live weight and condition score in Holstein Friesian dairy cattle. Anim. Sci. 64:385-392.

Veerkamp, R. F., M. P. Coffey, D. P. Berry, Y. de Haas, E. Strandberg, H. Bovenhuis, M. P. L. Calus, and E. Wall. 2012. Genome-wide associations for feed utilization complex in primiparous HolsteinFriesian dairy cows from experimental research herds in four European countries. Animal 6:1738-1749.

Veerkamp, R. F., G. C. Emmans, A. R. Cromie, and G. Simm. 1995. Variance components for residual feed intake in dairy cows. Livest. Prod. Sci. 41:111-120.

Veerkamp, R. F., H. A. Mulder, R. Thompson, and M. P. L. Calus. 2011. Genomic and pedigree-based genetic parameters for scarcely recorded traits when some animals are genotyped. J. Dairy Sci. 94:4189-4197.

Veerkamp, R. F., J. K. Oldenbroek, H. J. Van Der Gaast, and J. H. J. Van Der Werf. 2000. Genetic correlations between days until start of luteal activity and milk yield, energy balance, and live weights. J. Dairy Sci. 83:577-583.

Veerkamp, R. F., and R. Thompson. 1999. A covariance function for feed intake, live weight, and milk yield estimated using a random regression model. J. Dairy Sci. 82:1565-1573.

Vitezica, Z. G., I. Aguilar, I. Misztal, and A. Legarra. 2011. Bias in genomic predictions for populations under selection. Genet. Res. (Camb.) 93:357-366.

Waghorn, G. C., K. A. Macdonald, Y. Williams, S. R. Davis, and R. J. Spelman. 2012. Measuring residual feed intake in dairy heifers fed an alfalfa (Medicago sativa) cube diet. J. Dairy Sci. 95:1462-1471.

Williams, Y. J., J. E. Pryce, C. Grainger, W. J. Wales, N. Linden, M. Porker, and B. J. Hayes. 2011. Variation in residual feed intake in Holstein-Friesian dairy heifers in southern Australia. J. Dairy Sci. 94:4715-4725.

Zom, R. L. G., G. Andre, and A. M. van Vuuren. 2012. Development of a model for the prediction of feed intake by dairy cows: 1 . Prediction of feed intake. Livest. Sci. 143:43-57. 